\title{
ANALYSIS OF MACRONUTRIENTS CONTENT IN WINTER WHEAT GRAIN OF SPELT TYPE (Triticum aestivum ssp spelta L.) DEPENDING ON CROP PROTECTION, SEEDING STANDARDS AND VARIETY
}

\section{ANALIZA ZAWARTOŚCI MAKROSKŁADNIKÓW W ZIARNIE PSZENICY OZIMEJ TYPU ORKISZ (Triticum aestivum ssp spelta L.) W ZALEŻNOŚCI OD OCHRONY ŁANU, NORM WYSIEWU I ODMIANY}

\author{
Department of Herbology and Plant Cultivation Techniques, University of Life Sciences \\ in Lublin, Poland \\ ${ }^{1}$ Department of Agronomy, West Pomeranian University of Technology, Szczecin, Poland \\ 2Department of Chemistry, Microbiology and Environmental Biotechnology, West Pomeranian \\ University of Technology, Szczecin, Poland
}

\begin{abstract}
Streszczenie. Celem przeprowadzonych badań była ocena wpływu ochrony łanu i norm wysiewu na zawartość makroskładników (azot, fosfor, potas, wapń, magnez) w ziarnie dwóch odmian orkiszu - polskiej 'Rokosz' i niemieckiej 'Schwabenspelz'. Doświadczenie polowe przeprowadzono w latach 2014-2015 w miejscowości Czesławice, na glebie płowej wytworzonej z lessu, zaliczanej do kompleksu pszennego dobrego i II klasy bonitacyjnej, o odczynie lekko kwaśnym. Warstwa orna gleby charakteryzowała się wysoką zawartością przyswajalnych form fosforu i potasu oraz średnią zawartością magnezu. Materiał do analizy stanowiło ziarno orkiszu pszennego ozimego: I czynnik - ozime odmiany orkiszu, II czynnik - dwie normy wysiewu, III czynnik - ochrona łanu. Zbiór wykonano w fazie pełnej dojrzałości ziarna. Zawartość w ziarnie orkiszu ozimego trzech podstawowych makroskładników (azotu, fosforu i potasu) różnicował czynnik odmianowy. Porównywane odmiany nie różnicowały ilości magnezu i wapnia w ziarnie orkiszu ozimego. Odmiana 'Schwabenspelz' jest bardziej zasobna, niż odmiana 'Rokosz', w badane makroskładniki. Podwyższenie obsady roślin spowodowało istotne obniżenie zawartości azotu oraz wzrost ilości fosforu w ziarnie orkiszu ozimego. Zmiana ilości obsady roślin nie wpłynęła na zasobność ziarna orkiszu w metale wchodzące w skład makroskładników występujących w roślinach. Otrzymane w doświadczeniu wyniki nie wykazują istotnego wpływu sposobu ochrony łanu na zawartość makroskładników w ziarnie orkiszu ozimego.
\end{abstract}

Key words: winter wheat types spelt (Triticum aestivum ssp spelta L.), macroelements, crop protection, sowing ratio, cultivar.

Słowa kluczowe: pszenica ozima typu orkisz (Triticum aestivum ssp spelta L.), makroskładniki, ochrona łanu, normy wysiewu, odmiany.

\section{INTRODUCTION}

Winter wheat of spelt type (Triticum aestivum ssp spelta L.), commonly called spelt, is one of the oldest wheat subspecies cultivated 5000 years ago in the southern part of Asia. In Europe, popular for centuries, spelt has been supplanted in the nineteenth century by

Corresponding author - Adres do korespondencji: Marzena Gibczyńska, Department of Chemistry, Microbiology and Environmental Biotechnology, West Pomeranian University of Technology, Szczecin, Juliusza Słowackiego 17, 71-434 Szczecin, Poland, e-mail: Marzena.Gibczynska@zut.edu.pl 
increasingly cultivated wheat. For a long time in many European countries (mainly in Poland, Germany and Switzerland), a renaissance of the cultivation of this "ancient wheat" with a delicate flavor and mild taste, can be witnessed. Spelt is not subjected to genetic modifications, which allowed it to survive in its original form. Legislation both in the European Union and in Poland, treat spelt as a separate species (Triticum spelta L.). The area of crops on our continent in 2014 was about 60 thousand hectares. According to the Ministry of Agriculture and Rural Development, in 2009, the area of organic spelt plantation in Poland reached over 1.400 hectares. (Trajer and Mieczkowski 2010). The largest number of spelt varieties comes from Germany and Switzerland.

In March 2012, the first Polish , cultivar of winter spelt 'Rokosz' (breeding name STH 4809) obtained in Plant Breeding Center Strzelce Sp. o.o. - IHAR Group, by a team of breeders under the direction of Dr. Zygmunt Nita (the expiry date of entry 12/31/2022), was entered to the national list of cultivars. Plants of this, cultivar are very high, with low to very low resistance to lodging. Spelt, cultivar 'Schwabenspelz' comes from Germany and was issued by the Federal Office into German descriptive catalog of varieties in 2000 (Bundessortenamt/BSA 2005). Compared to the standard wheat cultivar Tonacja, this cultivar has a higher resistance to leaf rust, leaf septoria, FHB light, and chaff septoria (Słowiak et al. 2015).

Spelt is becoming more popular due to the possibility of cropping in low-input conditions, especially in organic farms. Its nutritional values are appreciated by consumers (Tyburski and Babalski 2006). Directive 2009/128/EC of the European Parliament and the Council of 21 October 2009 as well as Regulation (EC) No. 1107/2009, require to implement the principles of integrated pest management (IPM) in plant production. EU established the framework for Community action to achieve a sustainable use of pesticides and have been in place since 2014 (Directive 2009/128/EC; Regulation (EC) No. 1107/2009).

Compared to the traditional cropping system, every non-chemical methods that manage the problem with of agrophages are preferred. The basis of the recommendations will therefore be biological or agronomical methods or the use of a proper crop rotation with cross-compliance fertilization. Particular attention is paid to the introduction of plant varieties recommended for in specific region. In case of ineffective use of non-chemical methods controlling agrophages, it is acceptable to use the chemical control against them. Meanwhile, the economic threshold has to perform to minimize the risk of hazards to human health and natural environment.

Commonly known, that chemical composition of crops depends on many abiotic and biotic factors such as: soil and climatic conditions, agricultural practices, fertilization or attributes of cultivar.

There are few references providing the results of the macronutrients content in spelt grain in relation to agricultural practices The aim of present study was to evaluate the effect of crop protection method and seeding standards on the contents of macronutrients (nitrogen, phosphorus, potassium, calcium, magnesium) in grain of two spelt varieties ('Rokosz', 'Schwabenspelz').

\section{MATERIAL AND METHODS}

\section{Experimental details}

The field experiment was conducted in 2014-2015 in Czesławice ( $\left.\varphi=51^{\circ} 30^{\prime} \mathrm{N}, \lambda=22^{\circ} 28^{\prime} \mathrm{S}\right)$, at the Experimental Farm of University of Life Sciences in Lublin. The experiment was set up on lessive soil developed from loess classified as good wheat complex and second bonitation 
class, slightly acidic (PN-ISO 10390:1997P). The plowing layer of the soil was characterized by a high content of available forms of phosphorus, potassium and average magnesium. Humus content was $16.3 \mathrm{~g} \cdot \mathrm{kg}^{-1}$ soil. Material for analyses consisted of winter spelt grain obtained as an average from mixture.

Three fixed factors were studied with the treatments as follow:

I - winter spelt varieties (A - cv. 'Rokosz', Polish, B - cv. 'Schwabenspelz', German);

II - two standards of seeding ratio: Optimal $(x)-130 \mathrm{~kg} \cdot \mathrm{ha}^{-1} \mathrm{of} \mathrm{cv}$. 'Rokosz' and $200 \mathrm{~kg} \cdot \mathrm{ha}^{-1}$ of cv. 'Schwabenspelz', Increasedy (y) $-200 \mathrm{~kg} \cdot \mathrm{ha}^{-1}$ of cv. 'Rokosz' cv. kernels and $350 \mathrm{~kg} \cdot \mathrm{ha}^{-1}$ of $\mathrm{cv}$. 'Schwabenspelz' cv., III - crop protection:

a) mechanical by harrowing in early spring when vegetation of wheat started;

b) control object (no mechanical/chemical control);

c) chemical control of weeds by use of herbicides: Sekator 125 OD (amidosulfuron, methyl-sodium iodosulfuron) at $\mathrm{BBCH} 22-24$ at rate $150 \mathrm{~cm}^{3} \cdot \mathrm{ha}^{-1}$, and Attribut 70WG (sodium propoxykarbazon) at $\mathrm{BBCH} 22-24$ at rate $60 \mathrm{~cm}^{3} \cdot \mathrm{ha}^{-1}$;

d) full chemical control by use of herbicides: Sekator 125 OD (amidosulfuron, methylsodium iodosulfuron) at $\mathrm{BBCH} 22-24$ at rate $150 \mathrm{~cm}^{3} \cdot \mathrm{ha}^{-1}$, and Attribut $70 \mathrm{WG}$ (sodium propoxycarbazon) at $\mathrm{BBCH} 22-24$ at rate $60 \mathrm{~cm}^{3} \cdot \mathrm{ha}^{-1}$, anti-lodging agent Cerone $480 \mathrm{SL}$ (etephone) at $\mathrm{BBCH} 30-31$ at rate $0.75 \mathrm{dm}^{3} \cdot \mathrm{ha}^{-1}$, fungicide Wirtuoz $520 \mathrm{EC}$ (prochloraz, tebuconasole, proquinaside) at stages $\mathrm{BBCH} 24-25$ and $32-33$ at rate $1.0 \mathrm{dm}^{3} \cdot \mathrm{ha}^{-1}$, insecticide Decis 2,5 EC (deltametrin) at stage $\mathrm{BBCH} 37-39$ at rate $0.25 \mathrm{dm}^{3} \cdot \mathrm{ha}^{-1}$.

The target density for each standard was consistent with the amount of sowing determined by the germination capacity of the plants. In each year of the study, a pre-crop for spelt was winter wheat. Tillage was typical for field cultivation before wheat sowing. Mineral fertilizers were applied in the following doses: $50 \mathrm{~kg} \mathrm{~N} \cdot \mathrm{ha}^{-1}, 26 \mathrm{~kg} \mathrm{P} \cdot \mathrm{ha}^{-1}$ and $50 \mathrm{~kg} \mathrm{~K} \cdot \mathrm{ha}^{-1}$. The total amount of phosphorus, potassium and nitrogen fertilizers at $20 \mathrm{~kg} \mathrm{~N} \cdot \mathrm{ha}^{-1}$ was applied before sowing. The remaining amount of nitrogen fertilizer was used in the spring right after the start of vegetation. Plot size to sow and harvest was $13.5 \mathrm{~m}^{2}(5 \mathrm{~m} \times 2.7 \mathrm{~m})$. Spelt was sown in the last decade of September. A harvest was performed at full maturity stage of grain.

\section{Climatic conditions}

The average temperature recorded in the period of plant growth in 2013 and 2014 was much higher than the multi-year average. The vegetation period in 2015 was characterized by a temperature close to the average for 1963-2010.

Total rainfall during the growing season in 2013 and 2014 was higher by $34 \%$ as compared to the rainfall for 40 years, which is the basis for evaluation of this period as very humid. Particularly large amount of rainfall was recorded in May, June and August 2014. In 2015, the amount of rainfall was lower than that recorded in many-year period - the growing season can be classified as dry (85.5\% of the average value) - Kaczorowska (1962). 
Table 1. Temperature and rainfall sum in September-August as compared to the average for 1963-2010 according to the Meteorological Station in Czesławice

Tabela 1. Temperatura i suma opadów w miesiącach IX-VIII, w porównaniu ze średnimi z lat 1963-2010, wg Stacji Meteorologicznej w Czesławicach

\begin{tabular}{|c|c|c|c|c|c|c|}
\hline \multirow[t]{2}{*}{$\begin{array}{l}\text { Month } \\
\text { Miesiąc }\end{array}$} & \multicolumn{3}{|c|}{$\begin{array}{c}\text { Average monthly temperature } \\
\text { Średnia temperatura miesięczna } \\
{\left[{ }^{\circ} \mathrm{C}\right]}\end{array}$} & \multicolumn{3}{|c|}{$\begin{array}{c}\text { Sum monthly rainfall } \\
\text { Suma opadów miesięcznych } \\
{[\mathrm{mm}]}\end{array}$} \\
\hline & $2013 / 2014$ & $2014 / 2015$ & 1963-2010 & $2013 / 2014$ & $2014 / 2015$ & 1963-2010 \\
\hline September - Wrzesień & 11.3 & 14.0 & 13.1 & 49.5 & 21.8 & 59.5 \\
\hline October - Październik & 9.5 & 9.7 & 7.9 & 7.3 & 27.5 & 45.6 \\
\hline November - Listopad & 4.9 & 4.6 & 2.9 & 60.6 & 24.1 & 41.0 \\
\hline December- Grudzień & 1.7 & -0.1 & -1.3 & 13.7 & 57.8 & 36.9 \\
\hline January - Styczeń & -2.9 & 1.0 & -3.0 & 54.5 & 50.9 & 30.3 \\
\hline February - Luty & 0.3 & -1.1 & -1.7 & 5.8 & 15.8 & 29.2 \\
\hline March - Marzec & 4.9 & 2.8 & 1.8 & 49.1 & 48.6 & 31.3 \\
\hline April - Kwiecień & 8.9 & 6.5 & 7.7 & 63.9 & 39.1 & 42.4 \\
\hline May - Maj & 13.0 & 11.5 & 13.6 & 230.2 & 169.6 & 63.5 \\
\hline June - Czerwiec & 15.2 & 16.1 & 16.5 & 110.2 & 13.5 & 72.7 \\
\hline July - Lipiec & 19.6 & 19.0 & 18.3 & 61.4 & 52.6 & 80.0 \\
\hline August - Sierpień & 18.3 & 21.9 & 17.7 & 102.0 & 5.9 & 69.5 \\
\hline $\begin{array}{l}\text { Average / sum } \\
\text { Średnia / suma }\end{array}$ & 8.73 & 8.83 & 7.79 & 808.2 & 527.2 & 601.9 \\
\hline
\end{tabular}

\section{Methods of chemical analysis}

Winter spelt grain was analyzed by determining the overall content of nitrogen, phosphorus, potassium, calcium and magnesium. Nitrogen was determined in solution after grain mineralization in sulfuric acid ( $\mathrm{VI}$ ) with $\mathrm{H}_{2} \mathrm{O}_{2}$ - Kjeldahl method (PN-EN-ISO-5983-1: 2005). After digestion of spelt grain in a mixture of nitric acid (V) and chloric acid (VII) in a ratio of $1: 1$, the total content of potassium, calcium, and magnesium was determined in the grain using the atomic absorption spectrometer (Thermo Fisher Scientific Series ICE 3000). Phosphorus was determined colorimetrically using ammonium molybdate at $470 \mathrm{~nm}$ (PN-76/R-64781, 1976).

\section{Statistical analysis}

The results were statistically analysed with the use of analysis of variance of a completely randomised design. Replications were results from 2 years of investigation. Tukey's confidence half-intervals were calculated at the level $p=0.05$. The statistical analysis of the results was conducted using Statistical 10 software.

\section{RESULTS AND DISCUSSION}

\section{Analysis of factor I - winter spelt varieties}

In general, the quality of wheat grain is the result of genetic characteristics, soil and climate conditions and used agricultural practices (Czubacka and Rachoń 2012).

Nutritionally, spelt and its products are characterized as more valuable than wheat grain, mainly in terms of protein quality (Biel et al. 2010). Comparing with wheat, spelt has a lower demand for nitrogen. It is subject to easily lodging and gives lower yield in habitats abundant in nitrogen (Ceglińska and Cacak-Pietrzak 2009). 
Grain of spelt grown in present experiment was characterized by an average nitrogen content amounting to 18.2 and $22.6 \mathrm{~g} \mathrm{~N} \cdot \mathrm{kg}^{-1} \mathrm{DM}$, respectively for 'Rokosz' and 'Schwabenspelz' cv. (Table 2), which indicates significantly higher abundance in nitrogen of German cultivar. Pszenice... (2012), when reporting that average level of nitrogen in common wheat grain is $22.3 \mathrm{~g} \mathrm{~N} \cdot \mathrm{kg}^{-1} \mathrm{DM}$, also claims that content of macronutrients in grain is the species attribute in integrated, high-efficient production of common wheat and spelt.

Table 2. Contents of macronutrients in winter spelt grain $\left[\mathrm{g} \cdot \mathrm{kg}^{-1} \mathrm{DM}\right]$ depending on cultivar Tabela 2. Zawartość makroskładników w ziarnie orkiszu ozimego [ $\mathrm{g} \cdot \mathrm{kg}^{-1}$ p.s.m.] w zależności od odmiany

\begin{tabular}{|c|c|c|c|c|}
\hline \multirow{2}{*}{$\begin{array}{l}\text { Macroelements } \\
\text { Makroskładnik }\end{array}$} & \multicolumn{2}{|c|}{ Cultivar - Odmiana } & \multirow{2}{*}{$\begin{array}{l}\text { Mean } \\
\text { Średnia }\end{array}$} & \multirow{2}{*}{$\mathrm{HSD}_{0.05}$ for - dla } \\
\hline & 'Rokosz' & 'Schwabenspelz' & & \\
\hline Nitrogen - Azot - N & 18.200 & 22.600 & 20.400 & 0.996 \\
\hline Phospohorus - Fosfor - P & 4.870 & 5.450 & 5.160 & 0.269 \\
\hline Potassium - Potas $-\mathrm{K}$ & 4.470 & 4.150 & 4.310 & 0.125 \\
\hline Magnesium - Magnez - Mg & 0.712 & 0.764 & 0.738 & n.s. \\
\hline Calcium - Wapń - Ca & 0.177 & 0.182 & 0.179 & n.s. \\
\hline Sum - Suma & 28.430 & 33.150 & 30.790 & - \\
\hline
\end{tabular}

n.s. - not significant difference - różnica nieistotna.

Both phosphorus and potassium are the elements responsible for the correct course of photosynthesis at plants (Marschner 1995). Ceglińska and Cacak-Pietrzak (2009) underline that phosphorus content in the grain is a genetic factor. According to Grela et al. (1993), grain of spelt are characterized by a higher content of phosphorus $4.2-4.4 \mathrm{~g} \mathrm{P}^{\prime} \mathrm{kg}^{-1} \mathrm{DM}$ and potassium by $11.8 \%$ as compared to that of common wheat. Stankowski et al. (2016), when studying the contents of minerals in winter spelt grain depending on a growing system, nitrogen fertilization, and cultivar, recorded average phosphorus concentration of $4.22 \mathrm{~g} \mathrm{P} \cdot \mathrm{kg}^{-1} \mathrm{DM}$. Spelt grain grown in the experiment was characterized by an average phosphorus content amounting for 'Rokosz' and 'Schwabenspelz' varieties respectively 4.87 and $5.45 \mathrm{~g} \mathrm{P} \cdot \mathrm{kg}^{-1} \mathrm{DM}$ and German cultivar was significantly more abundant (Table 2). Relatively new varieties grown in the experiment contained more phosphorus than the range given in the literature (mean for experiment $5.16 \mathrm{~g} \mathrm{P} \cdot \mathrm{kg}^{-1} \mathrm{DM}$ ). Compared with the phosphorus content in wheat grain of Tonacja cv. considered as the standard, for which Rachon and Szumiło (2009) reported an average value of $3.8 \mathrm{~g} \mathrm{P} \cdot \mathrm{kg}^{-1} \mathrm{DM}$, spelt grain is clearly more abundant. Also Gembarzewski et al. (1995) found average phosphorus content in winter wheat grain at lower level from 3.8 to $4.3 \mathrm{~g} \cdot \mathrm{kg}^{-1}$.

Spelt grain grown in the experiment contained the average of $4.31 \mathrm{~g} \mathrm{~K} \cdot \mathrm{kg}^{-1} \mathrm{DM}$. Statistical analysis confirmed the influence of a cultivar on the potassium content in spelt grain; grain of 'Rokosz' cv. was more abundant $\left(4.47 \mathrm{~g} \mathrm{~K} \cdot \mathrm{kg}^{-1} \mathrm{DM}\right)$ - Table 2.

The average magnesium concentration in spelt grain from the experience was $0.738 \mathrm{~g} \mathrm{Mg} \cdot \mathrm{kg}^{-1} \mathrm{DM}$, which was the level characterizing common wheat grain (Woźniak and Makarski 2012). Amount of calcium in winter spelt grain was lower and averaged to $0.179 \mathrm{mg} \mathrm{Ca} \cdot \mathrm{kg}^{-1} \mathrm{DM}$. Compared varieties did not differentiate the amount of magnesium and calcium in winter spelt grain (Table 2). Relatively low quantity of calcium causes that when evaluating the metal contents included within the macronutrients present in the spelt grain, can be described using the following sequence $\mathrm{K}>\mathrm{Mg}>\mathrm{Ca}$.

Comparing the overall content of macronutrients in the grain of tested varieties, it should be noted that 'Schwabenspelz' cv. is more abundant and the difference is $4.72 \mathrm{~g} \cdot \mathrm{kg}^{-1} \mathrm{DM}$. 


\section{Analysis of factor II - two standards of seeding ratio}

One of the elements determining the quality of the crop is adequate plant density. Currently, there is little information in the literature about the optimum level of individual agronomic factors (date, depth and density of sowing) on the available varieties of winter spelt.

Table 3. Content of macronutrients in winter spelt grain $\left[\mathrm{g} \cdot \mathrm{kg}^{-1} \mathrm{DM}\right]$ depending on plant density Tabela 3. Zawartość makroskładników w ziarnie orkiszu ozimego $\left[\mathrm{g} \cdot \mathrm{kg}^{-1}\right.$ p.s.m.] w zależności od obsady roślin

\begin{tabular}{|c|c|c|c|c|}
\hline \multirow[b]{2}{*}{$\begin{array}{l}\text { Macroelements } \\
\text { Makroskładnik }\end{array}$} & \multicolumn{2}{|c|}{ Plants density - Obsada roślin } & \multirow[b]{2}{*}{$\begin{array}{l}\text { Mean } \\
\text { Średnia }\end{array}$} & \multirow[b]{2}{*}{$\mathrm{HSD}_{0.05}$ for $-\mathrm{dla}$} \\
\hline & $\begin{array}{c}\text { optimal } \\
\text { optymalna (x) }\end{array}$ & $\begin{array}{c}\text { increased } \\
\text { podwyższona }(y)\end{array}$ & & \\
\hline Nitrogen - Azot - N & 20.90 & 19.90 & 20.40 & 0.996 \\
\hline Phospohorus - Fosfor - P & 4.98 & 5.34 & 5.16 & 0.269 \\
\hline Potassium - Potas - K & 4.29 & 4.32 & 4.31 & n.s. \\
\hline Magnesium - Magnez - Mg & 0.711 & 0.765 & 0.738 & n.s. \\
\hline Calcium - Wapń - Ca & 0.189 & 0.170 & 0.179 & n.s. \\
\hline Sum - Suma & 31.07 & 30.49 & 30.79 & - \\
\hline
\end{tabular}

n.s. - not significant difference - różnica nieistotna.

The increase in plant density resulted in a statistically proven reduction of nitrogen content of the order $1 \mathrm{~g} \mathrm{~N} \cdot \mathrm{kg}^{-1} \mathrm{DM}$ and phosphorus increase by $0.3 \mathrm{~g} \mathrm{P} \cdot \mathrm{kg}^{-1} \mathrm{DM}$ in winter spelt grain. Changing the plant density had no effect on abundance of spelt grain with respect to potassium, magnesium and calcium, i.e. metals included in the macronutrients occurring at plants (Table 3).

\section{Analysis of factor III - crop protection}

The use of herbicides, i.e. synthetic or natural plant protection products, is an integral part of modern agriculture. This creates a need to control their impact on the quality of crops, since they may affect the metabolism of plants, which also causes changes in grain quality (Mularczyk et al. 2010; Wenda-Piesik 2016). Often, attempts are carried out to replace herbicides with other agrotechnical procedures. In the experiment, harrowing in early spring after the start of vegetation was applied, which was intended to kill the overwintering or survival stages of many pathogens and extraction of soil pests, which are then disposed by birds.

Results achieved in the experiment, which were subjected to statistical analysis, did not show a significant influence of the crop protection type on the content of macronutrients in winter spelt grain (Table 4).

Table 4. Content of macronutrients in winter spelt grain $\left[\mathrm{g} \cdot \mathrm{kg}^{-1} \mathrm{DM}\right]$ depending on the crop protection type Tabela 4. Zawartość makroskładników w ziarnie orkiszu ozimego $\left[\mathrm{g} \cdot \mathrm{kg}^{-1}\right.$ p.s.m.] w zależności od ochrony łanu

\begin{tabular}{|c|c|c|c|c|c|c|}
\hline \multirow{2}{*}{$\begin{array}{c}\text { Macroelements } \\
\text { Makroskładnik }\end{array}$} & \multicolumn{4}{|c|}{ Crop protection - Ochrona łanu } & \multirow{2}{*}{$\begin{array}{c}\text { Mean } \\
\text { Średnia }\end{array}$} & \multirow{2}{*}{$\mathrm{HSD}_{0.05}$ for - dla } \\
\hline & A & $\mathrm{B}$ & $\mathrm{C}$ & $\mathrm{D}$ & & \\
\hline Nitrogen - Azot - N & 20.50 & 20.00 & 20.80 & 20.30 & 20.40 & n.s. \\
\hline Phospohorus - Fosfor - P & 5.09 & 5.15 & 5.20 & 5.21 & 5.16 & n.s. \\
\hline Potassium - Potas - K & 4.40 & 4.25 & 4.28 & 4.31 & 4.31 & n.s. \\
\hline Magnesium - Magnez - Mg & 0.747 & 0.761 & 0.731 & 0.713 & 0.738 & n.s. \\
\hline Calcium - Wapń - Ca & 0.183 & 0.201 & 0.160 & 0.173 & 0.179 & n.s. \\
\hline Sum - Suma & 30.92 & 30.36 & 31.17 & 30.71 & 30.79 & - \\
\hline
\end{tabular}

n.s. - not significant difference - różnica nieistotna. 


\section{RECAPITULATION}

1. The content of three basic macronutrients in spelt grain: nitrogen, phosphorus and potassium, was varied for cultivars. Meanwhile two cultivars did not differ with the amount of magnesium and calcium in grain.

2. Schwabenspelz was more abundant than 'Rokosz' regarding to studied macronutrients, and the difference was $4.72 \mathrm{~g} \cdot \mathrm{kg}^{-1} \mathrm{DM}$.

3. Increasing the plant density resulted in significant proven reduction in the nitrogen content and increase in the amount of phosphorus in winter spelt grain. The amount of plant density did not affect the abundance of spelt grain in relation to metals included in macronutrients occurring at plants.

4. The crop protection treatments of winter spelt did not impact on the macronutrients content in grain.

\section{REFERENCES}

Biel W., Hury G., Maciorowski R., Kotlarz A., Jaskowska I. 2010. Wpływ zróżnicowanego nawożenia azotem na skład chemiczny ziarna dwóch odmian orkiszu (Triticum Aestivum ssp Spelta L.) [Effect of nitrogen fertilization on chemical composition of spelt wheat (Triticum Aestivum ssp Spelta L.) two varieties]. Acta Sci. Pol., Zootechnica 9(4), 5-14. [in Polish]

Bundessortenamt/BSA (Hrsg.). 2005. Beschreibende Sortenliste Getreide, Mais, Ölfrüchte, Leguminosen, Hackfrüchte. Hannover, Hrsg. Bundessortenamt Hannover.

Ceglińska A., Cacak-Pietrzak G. 2009. Mity a nauka: magiczne właściwości dzikich zbóż św. Hildegardy: orkisz, szarłat, komosa ryżowa. Wrocław, Wroc. Wydaw. Nauk. Atla 2, 170. [in Polish]

Czubacka M., Rachoń L. 2012. Wpływ poziomu agrotechniki na skład chemiczny ziarna pszenicy ozimej [Impact of agrotechnical level on the chemical composition winter wheat grain]. EPISTEME 15, 45-52. ISSN 1895-4421. [in Polish]

Directive 2009/128/EC of the European Parliament and of the Council of 21 October 2009 establishing a framework for Community action to achieve the sustainable use of pesticides. Official Journal of the European Union 4.11.2009 L 309/71.

Gembarzewski H., Obojski J., Stryczński S., Slenkiewicz U. 1995. Zawartość makro- i mikroelementów w glebach oraz roślinach ziemniaka i pszenicy ozimej z pól o wysokiej produkcyjności. Puławy, IUNG, 1-38. [in Polish]

Grela E., Matraz J., Kling C.J. 1993. Składniki pokarmowe w ziarnie orkiszu (Triticum spelta L.) [The nutrients in the grain spelled (Triticum spelta L.)]. Biul. Infor. Przem. Pasz. 32(4), 35-43. [in Polish]

Kaczorowska Z. 1962. Opady w Polsce w przekroju wieloletnim [Precipitation in Poland in long-period averages]. Pr. Geogr. 33, 107. [in Polish]

Marschner H. 1995. Mineral nutrition of higher plants. London, Academic Press, 66.

Mularczyk A., Narkiewicz-Jodko M., Gil Z., Urban M. 2010. Wpływ herbicydów na zdrowotność i jakość ziarna pszenicy ozimej na tle warunków pogodowych [The influence of herbicides on health and quality of winter wheat grain depending on weather conditions]. Prog. Plant Prot. 50(1), 482-490. [in Polish]

PN-76/R-64781. 1976. Pasze sypkie. Oznaczanie fosforu. [in Polish]

PN-EN-ISO-5983-1. 2005. Pasze. Oznaczanie zawartości azotu i obliczanie zawartości białka ogólnego. Część I. Metoda Kjeldahla. [in Polish]

PN-ISO 10390:1997P. Soil quality - determination of $\mathrm{pH}$. 
Pszenice - zwyczajna, orkisz, twarda. Uprawa i zastosowanie. 2012. Red. W. Budzyński. Poznań, PWRiL, 328. [in Polish]

Rachoń L., Szumiło G. 2009. Comparison of chemical composition of selected winter wheat species. J. Elem. 14(1), 135-146.

Regulation (EC) No. 1107/2009 of the European Parliament and of the Council of 21 October 2009 concerning the placing of plant protection products on the market and repealing Council Directives 79/117/EEC and 91/414/EEC. Official Journal of the European Union 24.11.2009 L 309/1.

Słowiak K., Pszczółkowski P., Żak I. 2015. Wyniki porejestrowych doświadczeń odmianowych i rolniczych w województwie małopolskim. Zboża ozime. Zboża jare. Ziemniak. Węgrzce, Małopolski Zespół Porejestrowego Doświadczalnictwa Odmianowego i Rolniczego, 44-50. [in Polish]

Stankowski S., Hury G., Makrewicz A., Jurgiel-Małecka G., Gibczyńska M. 2016. Analiza zawartości składników mineralnych w ziarnie orkiszu ozimego (Triticum Aestivum ssp Spelta L.) w zależności od systemu uprawy, nawożenia azotowego i odmiany [Analysis of the content of mineral components in grain of winter spelt (Triticum Aestivum ssp Spelled L.) depending on: tillage system, fertilization nitrogen and variety]. Inż. Ekolog. 49, 227-232. [in Polish]

Trajer M., Mieczkowski M. 2010. Rozwój rynku pszenicy orkisz w świetle koniunktury na żywność ekologiczną [Market development spelled in the light of the situation on organic food]. Biul. Infor. ARR 7(229), 34-37. [in Polish]

Tyburski J., Babalski M. 2006. Uprawa pszenicy orkisz poradnik dla rolników [Cultivation of spelled guide for farmers]. Radom, Centrum Doradztwa Rolniczego w Brwinowie Oddział w Radomiu, 1-25. [in Polish]

Wenda-Piesik A., Lemańczyk G., Pańka D., Piesik D. 2016. Risk assessment posed by diseases in context of integrated management of wheat. J. Plant Dis. Prot. 123, 3-18. DOI:10.1007/s41348-016-0008-1.

Woźniak A., Makarski B. 2012. Content of minerals in grain of spring wheat cv. Koksa depending on cultivation conditions. J. Elem. 17(3), 517-523.

\begin{abstract}
The aim of the study was to evaluate the effect of crop protection and seeding ratio on the contents of macronutrients (nitrogen, phosphorus, potassium, calcium, magnesium) in grain of two spelt cultivars: Polish 'Rokosz' and German 'Schwabenspelz'. The field experiment was conducted in Czesławice in 2014-2015 on lessive soil developed from loess classified as good wheat complex and II bonitation class, slightly acidic. The plowing layer of the soil was characterized by a high content of available forms of phosphorus, potassium and average magnesium. Material for analysis consisted of winter spelt grain. The first experimental factor: winter spelt varieties; second factor: two seeding ratios; third factor: crop protection. The harvest was performed at full grain maturity stage. Content of three basic macronutrients in spelt grain: nitrogen, phosphorus and potassium, was varied for cultivars. Meanwhile two cultivars did not differ with the amount of magnesium and calcium in grain. 'Schwabenspelz' was more abundant than 'Rokosz' regarding to studied macronutrients. The increase of plant density resulted in significant reduction in the nitrogen content and increase in the amount of phosphorus in winter spelt grain. The amount of plant density did not affect the abundance of spelt grain in relation to metals included in macronutrients occurring at plants. The crop protection treatments of winter spelt did not impact on the macronutrients content in grain.
\end{abstract}

